\title{
Tussen optimisme en realisme
}

\author{
Citation for published version (APA):
}

de Vries, H. (1999). Tussen optimisme en realisme. Maastricht University. https://doi.org/10.26481/spe.19990521hv

Document status and date:

Published: 21/05/1999

DOI:

10.26481/spe.19990521hv

Document Version:

Publisher's PDF, also known as Version of record

\section{Please check the document version of this publication:}

- A submitted manuscript is the version of the article upon submission and before peer-review. There can be important differences between the submitted version and the official published version of record.

People interested in the research are advised to contact the author for the final version of the publication, or visit the DOI to the publisher's website.

- The final author version and the galley proof are versions of the publication after peer review.

- The final published version features the final layout of the paper including the volume, issue and page numbers.

Link to publication

\footnotetext{
General rights rights.

- You may freely distribute the URL identifying the publication in the public portal. please follow below link for the End User Agreement:

www.umlib.nl/taverne-license

Take down policy

If you believe that this document breaches copyright please contact us at:

repository@maastrichtuniversity.nl

providing details and we will investigate your claim.
}

Copyright and moral rights for the publications made accessible in the public portal are retained by the authors and/or other copyright owners and it is a condition of accessing publications that users recognise and abide by the legal requirements associated with these

- Users may download and print one copy of any publication from the public portal for the purpose of private study or research.

- You may not further distribute the material or use it for any profit-making activity or commercial gain

If the publication is distributed under the terms of Article $25 \mathrm{fa}$ of the Dutch Copyright Act, indicated by the "Taverne" license above, 


\title{
Tussen Optimisme en Realisme 310
}

\author{
Rede
}

uitgesproken bij de aanvaarding van het ambt van

bijzonder hoogleraar in de Kankerpreventic en Gezondheidsbevordering ann de Universiteit Maastricht op vrijdag 21 mei 1999

door

Dr. H. de Vries 


\section{PPN. 183396278}

De leerstoel is ingesteld vanuege de Nederlandse Kankerbestrijding/Koningin Wilhelmina Fonds 
Mijnheer de Rector Magnificus, Zeer gewaardeerde toehoorders,

Ik wil deze rede beginnen met een voorbeeld uit de praktijk, omdat dit voorbeeld weergeeft waarover we het hebben als het gaat over kankerpreventie.

"Kijk mam, dit heb ik voor je meegenomen, een folder over verstandig zonnen. Die kregen we op school. Er staat ook iets in over de zonnebank. Daar lig je toch vaak onder?" Mevrouw Jansen pakt de folder van haar zoon en begint te lezen. "Te veel zon is gevaarlijk" zo leest ze. "Je huid kan er ouder door gaan uitzien. Je kunt er huidkanker van krijgen". "Dat is wel leuk en aardig", denkt ze, "maar ik vind het belangrijk om er goed uit te zien. $\lambda$ ls receptioniste kan ik het me niet permitteren om met een bleek gezicht achter de balie te zitten. En in de winter toon ik toch al zo gelig. Wat moet je zeggen als iemand dan tegen je zegt: goh wat zie jij er vandaag bleek uit? Mijn man vindt het me goed staan en heel veel vriendinnen doen het ook. Ik ga maar twee keer per week een uurtje onder de hoogtezon, dat is dus echt niet zo veel. Bovendien, kanker krijg je pas als je ouder bent. En nicmand in onze familie heeft kanker, dus dat overkomt me toch niet". Ze legt de folder weg. Ze is niet van plan iets te veranderen. Ze roept tegen haar zoon: "Jan, gooi maar weg, dit is niet voor mii!"”

Dit voorbeeld geeft weer waar het in de kankerpreventie om gaat. We proberen mensen te motiveren zich gezond te gedragen, zodat kanker kan worden voorkómen en zo vroeg mogelijk kan worden opgespoord. Maar, je kunt dan op een aantal problemen stuiten. Mensen associëren kanker snel met iets dat hen niet overkomt of dat pas later komt. Ze denken dat ze geen risicogedrag vertonen, ze zijn niet overtuigd van de voordelen van het gezonde gedrag en ze ervaren geen steun van anderen. Mochten ze wel willen veranderen, dan weten ze vaak niet hoe ze moeten omgaan met problemen die ze tegen kunnen komen. Dit alles zorgt er voor dat mensen in zo'n geval niet gemotiveerd zijn om te veranderen. In het voorbeeld heb ik zonnen genoemd, maar het had ook roken, ongezonde voeding, te weinig beweging kunnen zijn. Of het nict meedoen aan cen bevolkingsonderzoek, of het niet letten op waarschuwingstekens van kanker. Deze gedragingen zijn van belang bij de preventie van kanker.

\section{WAT IS KANKERPREVENTIE?}

Het zonet genoemde voorbeeld laat zien dat kankerpreventie zich niet bezig houdt met kankerpatiënten maar met gezonde mensen. Bij kankerpreventie is een onderscheid te maken tussen primaire, secundaire en tertiaire preventie. Met primaire preventie bedoelen we het voorkomen van kanker. Secundaire 
preventie richt zich op de vroege opsporing van kanker. De tertiaire preventic richt zich op de zorg voor zicken. Mijn lecrstocl richt zich op de primaire en secundaire preventic: het proberen te voorkómen en de vroege opsporing.

Per jaar krijgen ongeveer 60.000 mensen te horen dat ze kanker hebben. In 1996 stierven er 37.000 mensen door de gevolgen van kanker. De meest gevaarlijke soorten kanker bij mannen zijn longkanker, prostaatkanker en dikke darmkanker. In 1996 stierven hier respectievelijk 6770, 2458 en 2042 mannen aan. Bij vrouwen zijn de meest gevaarlijke soorten: borstkanker, dikke darmkanker en longkanker. In 1996 stierven hierdoor respectievelijk 3552, 2134 en 1801 vrouwen.

\section{OORZAKEN VAN KANKER}

Wat zijn de oorzaken van kanker? We kunnen een onderscheid maken tussen drie soorten factoren: biologische factoren, omgevingsfactoren en gedragsfactoren. Bij biologische factoren kunnen we denken aan leefrijd. Naarmate men ouder wordt, neemt het risico op het krijgen van kanker toe. De meeste kankcrs komen dus voor bij oudere mensen. Een andere factor is geslacht. Borstkanker komt rooral voor bij vrouwen en zeer zelden bij mannen. Weer ecn andere biologische factor is het genetisch materiaal. Recentelijk wordt stecds duidelijker dat sommige kankers erfelijk bepaald kunnen zijn, zoals borst-en darmkanker.

Met omgevingsfactoren worden kenmerken van de omgeving bedoeld. Hierbij kunnen we denken aan asbest, kankervenwekkende stoffen op het werk en her wonen en werken in landen waar veel zon is.

Met gedragsfactoren wordt het gedrag van de mens bedoeld, zoals roken, slcchte vocding, declname ann bevolkingsonderzoek, etc.. Gedrag blijkt ook van belang te zijn bij de biologische en omgevingsfactoren. Ondat biologische en omgevingsfactoren nict of heel moeilijk te veranderen zijn, is beschermingsgedrag heel belangrijk. Central staat dan de vraag hoe we omgaan met deze biologische en omgevingsfactoren on de risico's zo klein mogelijk te houden. Bijvoorbeeld, hoe gaan we om met asbest, wat kunnen we doen tegen blootstelling aan veel zonlicht?

De preventie die zich concentreert op de rol van gedrag nocmen we de gedragsgerichte preventie. Gedragsgerichte preventic richt zich dus op het voorkómen van een gezondheidsprobleem door het stimuleren van mensen en organisaties tot het vertonen van gezondheidsbevorderend gedrag en beleid. 


\section{KANKERPREVENTIE: WAT KUNNEN WE DOEN?}

Welke gedragingen kunnen bijdragen tot een hoger risico op kanker en wat kunnen we er aan doen? Is er wel reden tot optimisme? Ik wil een aantal risicogedragingen en hun gevolgen samenvatten. Laten we ecrst eens kijken naar de primaire preventie.

Primaire preventie Roken wordt geassocieerd met een derde van alle kankergevallen en wordt gezien als de meest belangrijke risicofactor voor kanker. Roken wordt vooral geassocicerd met longkanker. Ongeveer $90 \%$ van de sterfte door longkanker is te wijten aan roken. Maar, roken geeft ook een verhoogd risico op andere soorten kanker zoals kanker aan mond, keel, strottenhoofd, slokdarm, de alvlecsklier en de blaas. Het aanbevolen gedag is niet roken.

Slechte vocding wordt ook geassocieerd met een derde van alle kankergevallen. De exacte rol van voeding is complex en nog steeds niet helemaal duidelijk. Het eten van groente en fruit wordt geassocicerd met lagere risico's op mond-, kecl-, slokdarm-, maag- en longkanker. Het aanbevolen gedrag is twee stuks fruit per dag en 200 gram groente; dit is ongeveer vier groentelepels. Over de relatic tussen vet en kanker is men recentelijk iets anders gaan denken. De hoeveelheid vet heeft vermoedelijk geen invloed op het ontstan van borsten dikke darmkanker. Het is nog nict duidelijk of de consumptie van vlces een hoger risico geeft op het ontstaan van dikke darmkanker. Wel is overgewicht gerclatcerd aan cen verhoogd risico op borst- en baarmoederkanker. Bovendien, het gebruik van weirig vet verlaagt het risico op hart- en vaatziekten, overgewicht en suikerziekte. Teveel alcohol is ook geassocicerd met kanker, zoals keel- en strottenhoofdkanker, slokdarmkanker en borstkanker. Bovendien, de combinatic van roken en veel alcohol vergroot het risico nog weer cens extra. Er wordt aanbevolen om per week niet meer drie glazen alcohol te drinken. Daarnaast wordt de combinatic van alcohol en roken sterk afgeraden.

Recentelijk is duidelijk geworden dat te weinig beweging geassocieerd is met dikke darmkanker en borstkanker. Het is nog niet helemaal duidelijk hoeveel we moeten bewegen om kanker te voorkómen. Daarom wordt de richtlijn voor bijvoorbeeld hart- en vaatziekten gevolgd. Deze is voor volwassenen tenminste vijf dagen per week een half uur matig intensief bewegen.

Te vecl zonnen is slecht, zeker voor mensen met een lichte huid. Het aanbevolen gedrag is jezelf te beschermen tegen teveel zon. Dit kun je op verschillende manieren doen, zoals een anti-zonnebrandmiddel met factor 10-12 gebruiken, het vermijden van de zon tussen 12 en 15 uur, en het dragen van beschermende kleding. 
Secundaire preventie Voor de secundaire preventie kunnen we drie soorten gedragingen onderscheiden: passieve ontdekking, actieve ontdekking en je laten onderzoeken. Met passieve ontdekking bedoelen we het alert zijn op waarschuwingstekens van kanker. Met actieve ontdekking doet men zelfonderzock, zoals borst- en zaadbalonderzoek en inspectie van moedervlekken. Je laten onderzoeken gebeurt door anderen, bijvoorbeeld door de huisarts. Je laten onderzoeken gebeurt ook ujdens een bevolkingsonderzoek. In Nederland hebben we twee bevolkingsonderzoeken, een voor het opsporen van borstkanker en een voor het opsporen van baarmoederhalskanker. Voor het bevolkingsonderzoek naar borstkanker worden vrouwen tussen de 50 en 75 jaar elke twee jaar uitgenodigd. Voor het bevolkingsonderzoek naar baarmoederhalskanker worden vrouwen russen de 30 en 60 jaar elke vijf jaar uitgenodigd. In sommige landen zijn er berolkingsonderzoeken naar prostaat- en darmkanker. In Nederland vindt thans onderzock plaats om na te gaan of dergelijk onderzock zinvol is.

Recentelijk is er meer andacht voor de vrocge ontdekking van erfelijke belasting. Het is sinds cen antal jaren mogelijk om erfelijkheidsonderzock te doen. Dit soort onderzoek wordt bijvoorbeeld gedaan als een bepaalde vorm van kanker veel in een familie voorkomt. Tockomstig onderzoek zal duidelijk mocten maken wanneer het zinvol is voor Nederlanders zich te laten onderzoeken op erfelijke belasting, hoe ze het beste voorlichting kunnen krijgen, en of er ongewenste bijeffecten kunnen optreden, zoals denken dat kanker alleen crfelijk bepaald is en dat de leefwijze er niet meer toe doet.

\section{KANKERPREVENTIEF GEDRAG VAN DE NEDERLANDER}

Hoe staat het nu met het gedrag van de Nederlanders? Hierover zijn verschillende studies gedaan, onder andere door de Universiteit Maastricht. Elk van de studies gecft weer een iets ander beeld, dus dit overzicht is een benadering van wat bekend is. Van de volwassen Nederlanders rookt $34 \%$, eet $61 \%$ onvoldoende groente, eet $76 \%$ onvoldoende fruit, ongeveer $55 \%$ beweegt te weinig (60\% in de winter, $47 \% \%$ in de zomer), ongeveer $50 \%$ beschermt zich onvoldoende tegen de zon (31\% te weinig bij het zonnebaden; $72 \%$ te weinig tijdens het wandelen), $23 \%$ van de vrouwen doet niet mee aan het bevolkingsonderzoek borstkanker en de schattingen voor het percentage vrouwen dat niet mecdoet aan het bevolkingsonderzoek baarmoederhalskanker variëren tussen de 30 en $50 \%$ (waarbij de deelname het geringst is bij vrouwen met een lage opleiding). Kortom, er is nog werk te doen. 


\section{EFFECTIEVE GEZONDHEIDSBEVORDERING EN KANKERPREVENTIE}

Er zijn de afgelopen jaren talrijke ontwikkelingen geweest op het gebied van de kankerpreventie. Deze ontwikkelingen stemmen hoopvol voor de toekomst. Ik geef van de belangrijkste ontwikkelingen een kort overzicht.

Planningsmodellen Een belangrijke verandering gedurende de laatste twee decennia bij de gedragsgerichte preventie in het algemeen is de nadruk op planmatigheid. Deze planmatigheid heeft onder andere vorm gekregen door het planningsmodel van Larry Green, het PRECEDE-PROCEED model, en de Nederlandse bewerking ervan door Gerjo Kok. Het model dat ik gebruik is weer een variatie op deze modellen en onderscheidt drie fases. De eerste fase is de analyse van het probleem, de doclgrocp en de oorzaken voor ongezond gedag. De tweede fase is de ontwikkeling en het testen van interventies. De derde fase is de continuering van preventie door de implementatie van succesvolle interventies op grote schaal.

Modellen voor verklaring van gedrag Voor de analyse van het gezondheidsgedrag, een belangrijke stap voor de analyse van het probleem, maken we gebruik van modellen. Deze modellen geven aan wat de belangrijkste soorten redenen zijn waarom mensen zich ongezond gedragen. Deze redenen voor gedrag noemen we ook wel de gedragsdeterminanten.

Er zijn verschillende soorten gedragsdeterminanten van belang. Dit toonde ook het voorbeeld over mevrouw Jansen. Ze zei: "It ga maar twee keer per week een uur onder de boogteqon, dus dat is niet erg". Dit soort idecën noemen we risicopercepties. Vaak maken mensen verkeerde risico-inschattingen en schatten hun eigen gedrag te optimistisch in. Zo onderschatten ze dus hun risico op het krijgen van kanker.

Ze las: Te veel zon is gevaarlijk. Je buid kan er ouder door gaan uitrien. Je kunt er buidkanker van krijgen". Ze dacht: "The vind het belangrijk om er goed wit te iien. Als receptioniste kan ik het me niet permitteren om met een bleek gezicht acbiter de balie te zitten. Dit zijn dus voor haar voor- en nadelen van het gedrag. Deze bepalen iemands houding of attitude: iemands oordeel over een gedrag.

Ook zei ze: "Mijn man vindt bet me goed staan, en heel veet uriendinnen doen bet ook". Dit is een voorbeeld van sociale invloeden. Mensen laten zich beïnvloeden door wat andere mensen doen en door wat andere mensen vinden wat je moet doen.

Ook noemde ze problemen: "Wat moet je zeggen als iemand dan tegen je zegl: gob wat zie jij er vandaag bleek wit? Dit is een voorbeeld van de probleemsituaties die je verwacht als je ander gedrag gaat uitvoeren. Het kunnen omgaan met dit soort problemen is belangrijk. We noemen dit soort idecën ook wel eigen 
effectiviteitsvervachtingen: verwacht je dat jij effectief kunt omgaan met probleemsituaties?

Deze factoren - de risicopercepties, de atuitude, de sociale invloeden, de eigen effectiviteit - bepalen de motivatie van een persoon om het gedrag te veranderen.

Het nut van dit soort modellen is dat het je leert te zien waar precies de knelpunten voor verandering zitten bij cen bepaalde doelgroep. Soms is cen doelgroep niet overtuigd van de voordelen van het gedrag. Dan moet een interventie de voordelen van het gewenste gedrag benadrukken. Soms weet de doelgroep niet hoe ze moet omgaan met problemen die kunnen optreden als ze het nieuwe gedrag wil vertonen. Dan zal de interventie in moeten gaan op hoe je deze problemen kunt oplossen. Soms moeten alle determinanten aandacht krijgen in een interventic.

Nieuwe interventies Belangrijkc ontwikkelingen zijn er ook gewcest voor de ontwikkeling en evaluatic van interventies. Het bleek dat de programma's die gericht waren op het aanleren van kennis nauwelijks invloed hadden op het gedrag. Er zijn nieuwe methodes ontwikkeld. Ik zal een antal effectieve interventies beschrijven die ook in Nederland zijn toegepast. Zo krijgt u een idee over hoe kankerpreventic in de praktijk plaats vindt.

De afgelopen jaren is cr aandacht bestecd aan de ontwikkeling van interventies waarbij, met name jongeren, leren om te gaan met druk van anderen. Deze programma's worden ook wel sociale invloed programma's genoemd. De onderliggende gedachte is dat veel ongezond gedrag ontstaat doordat jongeren dit ongezonde gedrag overnemen door de druk van anderen. Gedurende een aantal lessen op scholen leren jongeren deze sociale druk te herkennen en hoe ze hierop kunnen reageren. Onderzoek toont aan dat met dit soort programma's het beginnen met roken soms met de helft kan worden teruggebracht. Ook successen voor de preventie van alcohol en voeding worden gerapporteerd.

Een andere belangrijke ontwikkeling is de aandacht voor de "community" methodes. Er zijn verschillende omschrijvingen van het begrip community. Een voorbeeld van een community is een wijk. Een bedrijf is ook een community. Een sportclub kun je ook opvatten als een community. Het is dus een soort leef- of werkeenheid. Kort samengevat komt cen community benadering er op neer dat je de mensen van een community zoveel mogelijk betrekt bij de voorbereiding, ontwikkeling en uitvoering van een interventie. In Nederland is bijvoorbeeld een succesvol community project geweest in Bergeijk. Hicrdoor gingen mensen gezonder eten. Ook zijn er succesvolle projecten geweest voor het stoppen met roken, bijvoorbeeld in Den Bosch en in bedrijven.

De afgelopen jaren zijn zelfhulpgidsen ontwikkeld. Een belangrijk kenmerk 
van zelfhulpgidsen is dat mensen stapsgewijs leren hun gedrag te veranderen. Zelfhulpgidsen hebben als voordeel dat je thuis het gedrag kan veranderen en dat je er niet voor naar groepscursusssen hoeft. In Nederland zijn zelfhulpgidsen ontwikkeld voor bijvoorbeeld gezonde voeding en stoppen met roken. Ze hebben resultaat. Ongeveer 10 a $15 \%$ van de mensen stopt met roken na het lezen van de gids, tegenover ongeveer $5 \%$ van de mensen die niet zo'n gids krijgt.

Een andere interessante methode is "health counseling". Je zou dit in het Nederlands kunnen vertalen als gezondheidsadvisering. Wat gebeurt er bij health counseling? Een hulpverlener, bijvoorbeeld cen arts, leert via een stappenplan hoe hij een persoon kan motiveren dit gedrag te veranderen. De ecrste stap is het nagaan of een persoon risicogedrag vertoont (bijvoorbeeld: rookt u?). De tweede stap is nagaan of de persoon gemotiveerd is het gedrag te veranderen. De derde stap is het nagaan van de knelpunten voor verandering: ziet de persoon voldoende voordelen van het gezonde gedrag; krijgt de persoon voldoende steun; kan hij omgaan met problemen en barrières? De vicrde stap is het maken van afspraken, bijvoorbeeld voor een vervolgconsult of voor gedragsverandering. De vijfde stap is het geven van extra informatic of hulp (bijvoorbeeld zelfhulpgidsen, nicotinckauwgom). De zesde stap is het geven van nazorg. De afgelopen jaren zijn verschillende succesvolle protocollen ontwikkeld voor bijvoorbeeld de huisarts, verloskundigen en verpleegkundigen.

Nicuw is "gezondheidsvoorlichting op maat". Gezondheidsvoorlichting op maat lijkt op health counseling, maar nu vindt het advies via cen brief plaats. Hoc werkt deze methode? Een persoon valt een lijst in met vragen over zijn gedrag en zijn idecën over dit gedrag. De lijst wordt gezonden naar een organisatie, bijvoorbeeld de universiteit. Daar leest een computer de antwoorden van de persoon. Elk antwoord wordt gekoppeld aan één bepaald advies. $\Lambda$ fhankelijk van het antwoord krijgt een persoon het ene of het andere advies. Alle adviezen zijn met zorg door experts samengesteld. Een persoon krijgt dus door de hulp van deze experts een serie van heel persoonlijke adviezen op alle vragen. Deze adviezen krijgt een persoon toegezonden via cen persoonlijke bricf. Deze methode blijkt voor roken bijna dezelfde effecten te hebben als groepscursussen: ongeveer 20 to $25 \%$ van de rokers stopt met roken. De voordelen van de voorlichting-op-maat methode zijn het persoonlijk karakter en het feit dat je er veel mensen mee kunt bereiken. Inmiddels zijn er effectieve interventics ontwikkeld voor rookpreventic, stoppen met roken, voeding en zonnebaadgedag. Op dit moment testen we of deze methode ook kan worden gebruikt om mensen alerter te maken op de waarschuwingstekens van kanker.

Een recente ontwikkeling richt zich op beleidsveranderingen bij bedrijven en supermarkten. Bij een aantal bedrijven wordt het aanbod van voeding in de kantine veranderd om na te gaan of mensen ook hun voedingspatroon veran- 
deren. Bij een aantal supermarkten wordt gezonde voeding voorzien van bepaalde labels om mensen makkelijker een gezonde keuze te kunnen laten maken.

\section{KANKERPREVENTIE, WAT KAN BETER?}

De afgelopen jaren zijn er effectieve interventies ontwikkeld. Toch zien we nog veel risicogedrag. Hoe kan dit? Hiervoor zijn verschillende verklaringen. Ik nocm cen aantal.

Kennis Weten we wat we moeten doen? Soms blijkt dat Nederlanders nog niet weten wat het gewenste gezonde gedrag is. Een recent onderzoek over zonnen late zien dat de meeste ouders zichzelf en hun kinderen wel beschermen als ze op het strand en in het zwembad zijn. Veel minder bescherming vindt plaats in andere situatics waar men ook is blootgesteld aan de zon, zoals tijdens het wandelen en fietsen. Mogelijk is de voorlichting te veel geassocicerd met het doclbewuste zonnen (zoals zonnen aan zee, in de tuin), maar minder met andere risicovolle situatics. Bij vocding is het ook denkbaar dat het niet geheel duidelijk is wat we wel en niet mogen eten en hoevecl we moeten eten. Uit een studie blijkt dat veel Nederlanders de acht waarschuwingstekens van kanker niet kennen. Mannen kennen ze nog slechter dan vrouwen. Ik noem ze dan ook nog even kort: 1 . heesheid en hoest die langer duurt dan 6 weken; 2 . een wondje of zweertje dat niet geneest; 3 . veranderingen in de huid; 4 . aanhoudende slikklachten; 5 . knobbels of verdikkingen; 6. abnormaal bloedverlies; 7 . veranderingen in de stoclgang; 8 . gewichtsverlies zonder dat daar anleiding voor is.

Weten we wat we doen? Veel mensen blijken hun gezondheidsgedrag niet goed in te schatten. Met name mensen die ongezond leven, maken verkeerde en te optimistische inschattingen over hun gedrag. Van degenen die te weinig groente en fruit eten, meent $88 \%$ voldoende groente en $65 \%$ voldoende fruit te eten. Van de mensen die zich onvoldoende hebben beschermd tegen de zon, denkt $90 \%$ dat ze zichzelf wèl goed beschermen. Veel mensen schatten hun risico's op het krijgen van kanker daardoor te laag in. Ze denken het goed te doen, en zien dus geen redenen om hun gedrag te veranderen

Kortom, een deel van de Nederlandse bevolking blijkt nog te weinig kennis te hebben van een aantal kankerpreventieve gedragingen. Ook blijken ze vaak hun eigen gedrag niet te kennen en zijn te optimistisch. Op dit gebied kan dus nog het een en ander worden verbeterd.

Doelgroep Bij de keuze van de doelgroepen noem ik twee problemen. Allereerst richten de interventies zich vaak op één groep. Soms blijkt deze groep tc 
bestaan uit meerdere specifieke groepen, bijvoorbeeld mensen uit rijke buurten en achterstandswijken. Vaak is er een onderscheid tussen mensen die wel en nict gemotiveerd zijn hun gedrag te veranderen. Soms hebben deze specifieke groepen een aparte benadering nodig. Dit noemen we doelgroepsegmentatie.

Het tweede probleem is dat veel interventies zich richten op individuen. Dit niveau noemen we ook wel het microniveau. Veel minder interventies richten zich op het veranderen van gedrag en beleid van organisatics en het overheidsbeleid. Deze niveaus noemen we wel het meso- en het macroniveau. Er is veel minder aandacht voor de ontwikkeling van effectieve interventies om het gezondheidsbevorderend gedrag op deze niveaus te veranderen. Bijvoorbecld, er zijn in de wetenschappelijke literatuur veel studies te vinden over de effectiviteit van rookpreventieprogramma's. Er zijn echter nauwclijks studies te vinden die een interventic evalueren waarin het rookpreventiebcleid van scholen is veranderd.

Het is mijns inziens niet realistisch grote veranderingen te verwachten bij individuen als ook het gezondheidsbevorderend gedrag op het meso- en macro niveau niet wordt veranderd. Kortom, alle niveaus moeten onze aandacht hebben.

Determinanten onderzoek. Het onderzoek naar de gedragsdeterminanten (de oorzaken van gedrag) is nog steeds in ontwikkeling en kan verbeterd worden. $\mathrm{Ik}$ wil dit illustreren aan de hand van drie voorbeelden.

Veel determinantenonderzock is gebasecrd op een momentopname. Dit soort onderzoek noemen we cross-sectioneel onderzock. Dit onderzoek kan informatief zijn, maar heeft ook beperkingen. Onderzoek dat de rol van de gedragsdeterminanten over een langere tijd bestudeert is daarom belangrijk. Dit type onderzoek heet longitudinaal onderzoek. Hiermee kunnen we beter nagaan welke determinanten gedragsverandering verklaren.

Bij het onderzoek naar iemands attitude worden vaak verschillende opvattingen gemeten. We kunnen een onderscheid maken tussen de zogenaamde rationele en emotionele overwegingen. De verwachting later spijt te krijgen, een emotionele overweging, blijkt bijvoorbeeld een belangrijke verklaring voor vrouwen om wel mee te doen aan het onderzoek naar borstkanker. Emotionele redenen krijgen mogelijk te weinig aandacht in het determinanten onderzoek, en dus mogelijk ook te weinig aandacht in interventies.

De huidige methodes brengen mogelijk de rol van sociale invloeden onvoldoende in kaart. Recente studies over rookpreventie suggereren een minder grote rol van vrienden en een grotere rol van de ouders. De huidige methodes ontberen echter een gedetailleerd onderzoek naar de invloed van sociale netwerken waarbij de invloed van verschillende personen nauwgezet in kaart wordt gebracht. Op dit moment wordt deze methode gebruikt in een groot- 
schalig Europees onderzoek over rookpreventie. Dergelijke analyses zijn vermoedelijk ook van belang voor andere kankerpreventiegedragingen.

Betere interventies De afgelopen jaren zijn veel interventies ontwikkeld en geëvalueerd. Toch zijn cr ook veel interventies nict ontwikkeld of niet geëvalueerd. Nu kun je ook niet alles meteen doen. Ik zie dan ook verschillende mogelijkheden voor de toekomst. Bijvoorbeeld, van sommige folders weten we niet of ze effectief zijn en wat de effectieve ingrediënten ervan zijn. Een ander voorbeeld. Er zijn op dit moment geen effectieve methodes om jongeren tussen de 15 en 25 jaar te stimuleren te stoppen met roken. Nog een voorbeeld. Van de voorlichting over zonnen weten we niet of de volwassenen hierdoor ook echt hun zonnebaadgedrag gaan veranderen. Kortom, op dit gebicd zijn verschillende mogelijkheden voor de ontwikkeling en evaluatie van interventies.

Een ander problecm is dat de effecten van interventies op den duur uitdoven. Bijvoorbeeld, een jaar na het programma worden nog wel effecten gevonden, maar na vijf jaar is er geen effect meer. Sommigen beweren dan dat gedragsgerichte preventic nict eche effecticf kan zijn. Dit vind ik te voorbarig. Een probleem is natuurlijk dat als de interventic is opgehouden, er allerlei soorten invloeden kunnen zijn die weer een andere tegenovergestelde werking kunnen hebben. Je kunt hierbij bijvoorbeeld denken aan het effect van reclame. De uitdaging is dan ook om interventies te ontwikkelen die langdurige effecten zullen hebben. Dit betekent vermoedelijk langdurige programma's en ook langdurige cvaluaties.

Er zijn nog niet veel interventies ontwikkeld met als doel het veranderen van het gedrag en beleid van organisatics. Mecr aandacht voor het meso- en macroniveau betekent dan ook de ontwikkeling en evaluatie van interventiestudies op deze niveaus. Ik sta te popelen om bijvoorbecld een studie te starten waarbij we het rookbeleid van restaurants in Nederland eindelijk eens gaan veranderen. Ik roep hierbij de Stichting Volksgezondheid en Roken op om samen zo'n studie te doen. Mogelijk kunnen we een soortgelijke studie starten met het Voedingscentrum voor het creëren van een keten van gezonde restaurants die op hun kaarten menu's met voldoende groente hebben.

Wat is effect? Veel interventiestudies concentreren zich vooral op het veranderen van gedrag. Ze richten zich daardoor niet op het deel van de bevolking dat niet gemotivecrd is het gedrag te veranderen. Waarom is er zo' $n$ aandacht voor deze kleine gemotiveerde groep? Verandering van gedag wordt gezien als hét belangrijkste criterium voor succes van interventics. Maar is dit realistisch? De recente inzichten over de motivationele stadia leren ons dat cen groot deel van de bevolking niet gemotiveerd is het gedrag te veranderen. Bijvoorbecld, zeker $60 \%$ van de rokers is niet gemotiveerd het gedrag te veranderen. Effectstudies 
zullen dan ook niet meteen gedragsverandering kunnen aantonen bij deze groep. Vergelijkbare conclusies kunnen worden getrokken voor andere gedragingen, zoals voeding. Kortom, als we ons willen richten op het overgrote deel van de bevolking zal veelal het ecrste doel motivatieverhoging moeten zijn. Daarna kunnen we ons pas richten op ons uiteindelijke doel: gedragsverandering. Wat betekent dit dan voor effectstudies? Allerecrst moet er aangegeven worden op welke doclgrocp we ons richten en welke verandering realistisch is: veranderen van motivatie of veranderen van gedrag. Ten tweede moeten we ons realiseren dat interventies en evaluatiestudies vaak langer zullen moeten duren dan vier jaar, de periode dat er meestal subsidie wordt gegeven voor een project. Kortom, er is in het verleden te weinig aandacht geweest voor de ontwikkeling van interventies voor mensen die niet geünteresseerd waren om hun gedrag te veranderen.

Impact Een reden voor beperkte effecten op landelijk niveau kan ook cen gebrekkige impact van interventies zijn. Naast de effectiviteit is het belangrijk to inventariseren of interventies ook voldoende mensen weten te bereiken. Bijvoorbeeld, van groepscursussen is bekend dat ze behoorlijk effectief zijn. Echter, weinig mensen zullen ze bezoeken. Het effect zal zijn dat ze landelijk gezien cen beperkte impact hebben. In het huidige onderzock wordt mogelijk teveel gelet op de effectiviteit en te weinig op de impact. Iets minder effectieve interventies maar met een heel grote impact zijn interessanter voor de kankerpreventie dan interventies met een groot effect maar met een zeer geringe impact. Ik pleit overigens niet voor de afschaffing van groepscursussen. Wel pleit ik voor de ontwikkeling van effectieve interventics die ook veel impact hebben. Toekomstig onderzoek zal dan ook moeten proberen na te gaan of het mogelijk is de impact van interventies te kunnen schatten.

Implementatie Landelijke effecten van een goede interventic zullen alleen zichtbaar worden als het programma ook wordt gebruikt in de praktijk. Echter, de ontwikkeling van een effectieve interventie garandeert nict automatisch het gebruik ervan in de praktijk. De vertaalslag naar een effectieve interventie in de praktijk kan op verschillende manieren schipbreuk lijden.

Recentelijk werd weer eens op een Europees congres geconcludeerd dat veel kennis niet goed wordt vertaald door mensen in de praktijk. Dit betekent dat we meer moeten investeren in een goede vertaalslag van de theorie naar de praktijk. Mogelijk moeten programmaontwikkelaars meer in contact worden gebracht met degenen die dit soort programma's oorspronkelijk ontwikkelden.

$\mathrm{Bij}$ de invoering van een programma moeten soms concessies worden gedaan. Laat ik een concreet voorbeeld geven. Internationaal wordt aanbevolen om tenminste 10 lessen te besteden aan rookpreventie. In de praktijk vindt 
men dit teveel. Begrijpelijk? Leren we rekenen in vijf lessen, leren we autorijden in drie lessen? Een kwalitatief goede interventie vraagt cen bepaalde tijd. Wil men deze er niet aan besteden, dan kan de interventie mogelijk beter achtenvege worden gelaten. Anders lopen we nog het gevaar dat men zegt: zic je nou wel, preventic werkt niet! Preventic impliceert prioritering en geen schijnoplossingen.

Bij implementatieprocessen zijn veelal meerdere belanghebbenden. Voor een goed implementaticbeleid is het nodig hen te betrekken bij het gehele proces. Het is verstandig dit zo vroeg mogelijk te doen. Belanghebbenden kunnen dan al in een vroeg stadium hun wensen en idceën kenbaar maken. Hiermee kan dan bij de ontwikkeling van een interventie rekening worden gehouden.

Het is verheugend dat de samenwerking tussen de Universiteit Maastricht en een aantal organisatics de afgelopen jaren is geïntensiveerd. Er zijn structurele samenwerkingsverbanden met het Koningin Wilhelmina Fonds en de Stichting Volksgezondheid en Roken. Er zijn ook goede, niet geformaliseerde samenwerkingsverbanden met bijvoorbecld het Voedingscentrum en het $\mathrm{Ne}$ derlands Instituut voor Gezondheidsbevordering en Ziektepreventie. Dit stemt optimistisch.

Grenzen van voorlichting Onlangs werd me de vraag gesteld of ik niet moest constateren dat de voorlichting over het roken mislukt was omdat nog steeds zoveel mensen rookten. Ik antwoordde dat het percentage rokers bij mannen sinds 1950 met zo'n $30 \%$ is afgenomen en dat dit vooral te danken was aan de goede voorlichting over roken en effectieve stopmethodes. Ik denk dat het percentage rokers ook weer zou toenemen als deze voorlichting er net meer zou zijn. Voorlichting is echter geen wondermiddel. Je kunt er niet alles mee bereiken. De effectiviteit van voorlichting wordt mede bepaald door beleid. Als voorlichting gepaard gaat met beleid dat een andere boodschap verkondigt, zal het effect van voorlichting beperkt zijn. Een aantal jongeren zei eens tegen me: "Waarom zoveel aandacht voor rookpreventie? Als het echt slecht was zou de overheid het wel verbieden in bioscopen, sportkantines en restaurants. Je mag niet heroine spuiten, want heroine spuiten is slecht. Roken mag wel, dus roken zal wel niet slecht zijn". Dit voorbeeld laat het belang zien van een integrale benadering waarbij voorlichting en beleid cenzelfde boodschap uitdragen.

Een goed kankerpreventiebeleid vereist dat het gezonde gedrag makkelijk en het ongezonde gedrag moeilijk toegankelijk is. Recentelijk zijn er discussies geweest over het verbieden van de verkoop van tabak aan minderjarigen. Echter, zo'n verbod is moeilijk te controleren. Er zijn alternatieven die overwogen kunnen worden, zoals het terugdringen van het aantal verkooppunten, en het 
verhogen van de prijs. Studies suggereren minder tabaksverslaving bij een hogere prijs. Bijvoorbeeld, een $10 \%$ hogere prijs van sigaretten leidt tot een afname van ongeveer $5 \%$ in de consumptie en prevalentie. Ook bij voeding is een goed prijsbeleid belangrijk voor het stimuleren van gezonde voeding. Als de meest gezonde voeding ook de duurste voeding is, zal dit een reden kunnen zijn om een goedkoper en minder gezond alternatief te kiezen.

Kortom, we moeten geen overspannen verwachtingen hebben van voorlichting, zeker niet als dit niet gepaard gaat met een duidelijk en gelijkluidend gezondheidsbevorderend beleid.

\section{UITDAGINGEN VOOR DE TOEKOMST}

Tot slot van deze rede wil ik een aantal onderzoeksthema's noemen voor de primaire en secundaire kankerpreventie die mijns inziens voor de toekomst van belang zijn. Deze thema's zullen ook hun beslag moeten krijgen in het onderwijs om studenten en gezondheidsintermediairen voldoende voor te bereiden op de praktijk. Anders gezegd, wat zullen belangrijke missies zijn? In het voorgaande heb ik hierover al het een en ander laten doorschemeren. Ik vat de punten nog even samen.

Betere kennis en risicopercepties Soms weten Nederlanders nog niet precies wat het gezonde gedrag is. Deze kennis moet worden verbeterd. Soms weten Nederlanders niet wat ze doen. Ze maken dan veelal te optimistische inschattingen over hun gedrag en zien geen reden om te veranderen. Toekomstig onderzoek moet zich allerecrst richten op het verbeteren van deze kennis. Ten tweede moet het zich richten op de ontwikkeling van methodes om goede risico inschattingen te kunnen maken, bijvoorbecld door meer persoonlijke informatie te geven over het gedrag en de eventuele risico's crvan.

Onderzoek naar de gedragsdeterminanten Het is belangrijk om de redenen voor gezond en ongezond gedrag te begrijpen. Bestaande verklaringsmodellen zullen kritisch onder de loep moeten worden genomen en hierbij moet meer gebruik worden gemaakt van longitudinale studies. Ook zal er meer aandacht moeten worden besteed aan de rol van emotionele overwegingen. Om sociale invloed processen beter in kaart te brengen, kunnen andere methodes - zoals de sociale netwerk methode - zinvol zijn.

Effectieve interventies Toekomstig onderzoek zal zich moeten richten op de ontwikkeling van effectieve interventies voor bepaalde groepen van de bevolking, zoals verschillende motivationele groepen en achterstandsgroepen. Naast andacht voor voorlichting is ook aandacht voor verandering van beleid van 
organisaties van belang. Voor het bestuderen van de effecten zullen mogelijk ook andere methodes gebruikt moeten worden dan de gerandomisecrde studies, zoals data-triangulatic waarbij bewijzen voor effectivitcit uit verschillende bronnen worden verzameld. Effectstudies moeten zich richten op zowel motivatie- als gedragsverandering en op het realiseren van langdurige effecten. Voor het beoordelen van het resultaat van interventies zal niet alleen gekeken moeten worden naar het effect, maar ook naar de impact.

Implementatie Effectieve voorlichtingsmethodes en -protocollen worden niet auromatisch ingevoerd. Het effecticve rookpreventieproject dat indertijd is ontwikkeld en gefinancierd door de Nederlandse Kankerbestrijding, is helaas maar mondjesmaat gebruikt bij scholen in Nederland. Gelukkig zijn cr ook methodes die wel worden geadopteerd door organisaties, zoals het $A d v i e s$ over Roken op Maat door de Stichting Volksgezondheid en Roken. Toch verloopt de acceptatie en het gebruik van nieuwe methodes vaak langzaam. Toekomstig onderzock zal zich enerzijds moeten richten op het analyseren van barrières voor implementatie en anderzijds op het ontwikkelen en testen van implementatiestrategieën.

De plaats van preventie De volgende missic is niet een onderzocksmissic, maar cen beleidsmissic. In de toekomst is het belangrijk de toenemende rol van de gedragsgerichte preventie verder vorm te geven. De gedragsgerichte gezondheidsbevordering heeft zich de afgelopen jaren ontwikkeld tot cen aparte discipline, met als belangrijke kenmerken de planmatige aanpak, de analyse van gezondheidsgedrag en de determinanten ervan, de ontwikkeling en evaluatie van interventies, en de implementatie van effectieve interventies. In het algemeen is er nog steeds cen onbalans tussen curatie en preventie: teveel aandacht gaat uit naar de curatie. Een uitdaging voor de volgende eeuv is deze onbalans tc herstellen. De gedragsgerichte preventie moet hierin een essentiële rol krijgen. Onderkenning van het belang van de gedragsgerichte preventic betekent in toenemende mate een belangrijkere rol voor de gedragsgerichte kankerpreventie in verschillende instellingen - zoals GGD-en, de thuiszorg, bedrijven, de nieuve gezondheidscentra - met als doel preventiebeleid. De Nederlandse Vereniging voor Preventie en Gezondheidsbevordering kan in dit proces een belangrijke rol spelen. Dit kan bijvoorbeeld door het registratietraject van gedragsgerichte preventiewerkers verder vorm te geven. Registratie heeft immers tot doel de kwaliteit van gedragsgerichte gezondheidsbevordering te bevorderen. Ook kan men zich hard maken voor een registratie van effectieve activiteiten. $\mathrm{Er}$ is immers een wezenlijk verschil tussen geloof en wetenschap. "Evidence based health promotion" ofwel, gezondheidsbevordering op basis van effectief bewezen methodes, is essenticel voor kwalitatief hoogstaande 
gezondheidsbevordering en kankerpreventic.

Kortom, de gedragsgerichte preventic moet verder maatschappelijk worden erkend en een grotere rol krijgen bij de ontwikkeling en uitvoering van het beleid omtrent de gezondheidsbevordering.

\section{SLOT}

Met deze rede heb ik een indruk gegeven van het vakgebied van de kankerpreventie en de gezondheidsbevordering. De leerstoel is ingesteld in 1998. Ze is in de gelukkige positie dat ze kan voortbouwen op werk dat gedurende ruim 10 jaar is verricht door verschillende onderzoekers bij de Universiteit Maastricht in samenwerking met cen groot aantal instantics in Nederland. Veel van dit werk vond plaats binnen het kader van een zogenaamde aandachtsplaats "Primaire Kankerpreventie". Deze aandachtsplaats was mogelijk door een initiatief van de Nederlandse Kankerbestrijding/Koningin Wilhelmina Fonds, cen van haar vele activiteiten van de afgelopen 50 jaar.

Ik hoop dat de rede $u$ duidelijk heeft gemaakt dat er zeker aanleiding is tot optimisme: we hebben methodes om de motieven voor ongezond gedrag te kunnen begrijpen, methodes om mensen te motiveren zich gezonder te gedragen en methodes om succesvolle interventies landelijk te implementeren. Op dit terrein is reeds grote vooruitgang gebockt en is in de tockomst verdere vooruitgang mogelijk. We moeten ook realistisch blijven. Mensen zijn soms onvoldoende op de hoogte van bepaalde risicogedragingen en van hun eigen gedrag. We weten tevens dat kanker zal blijven voorkomen, zeker bij een ouder wordende populatie. We weten ook dat menselijk gedrag en het beleid van organisaties vaak lastig te veranderen zijn. Toch is er op verschillende gebieden vooruitgang geboekt. Dit stemt hoopvol voor de toekomst.

\section{DANKWOORD}

Aan het einde van mijn rede wil ik graag enkele woorden van dank uitspreken.

Allereerst wil ik het College van Bestuur van de Universiteit Maastricht en het Bestuur van de Faculteit der Gezondheidswetenschappen bedanken voor mijn aanstelling.

Vervolgens wil ik de Nederlandse Kankerbestrijding/Koningin Wilhelmina Fonds bedanken voor de instelling van deze leerstoel. Deze aanstelling biedt de mogelijkheid om het onderzoek naar kankerpreventie te continueren en verder uit te bouwen. Ik wil ook de medewerkers van de Nederlandse Kankerbestrijding bedanken voor de prettige samenwerking dic we de afgelopen jaren hebben gehad en wil met name Karel van Koppen en Cora Honing bedanken. IWe hebben denk ik een unieke samenwerking weten op te bouwen waarbij er 
sprake is van een zeer vruchtbare interactic tussen vragen uit de praktijk en inzichten uit de wetenschap. Ik hoop dat deze vorm van interactie nog lang zal kunnen bestaan.

Vervolgens wil ik Gerjo Kok bedanken. Gerjo, je hebt de afgelopen jaren immens veel gedaan voor de ontwikkeling van de gedragsgerichte preventic. Bij een gelegenheid als deze realiseer ik me weer opnieuw het belang van jouw wetenschappelijke input en inspiratie. Bovendien, zonder jouw steun zou er vermoedelijk geen aandachtsplaats kankerpreventic noch lecrstoel kankcrpreventie en gezondheidsbevordering zijn geweest. Ik wil je ook bedanken voor het vertrouwen dat je in me hebt gesteld - al vanaf mijn studietijd in Groningen - door me de mogelijkheid te geven te promoveren en daarna zelfstandig een onderzoekslijn op te zetten. Ik hoop dat we in de toekomst vruchtbaar zullen blijven samenwerken.

Waarde collega's van de capacitcitsgroep Gezondheidsvoorlichting. Ik wil jullie bedanken voor de samenwerking, steun en inspiratie. Hicrbij wil ik ook de hulp van het ondersteunend personeel betrekken. Ook wil ik Gerard van Breukelen van de vakgroep Methodologie en Statistiek bedanken voor zijn statistische hulp bij ons onderzock. Daamaast wil ik last but not least - niet met name want daarvoor zijn het er teveel maar wel expliciet - alle onderzoekers en promovendi bedanken die betrokken zijn geweest bij de ontwikkeling van dezc leerstoel. Dankzij jullie werk heb ik veel geleerd en zonder jullie werk was deze leerstoel er niet geweest.

Waarde collega's van de onderzoeksinstituten HEALTH, ExTra en NUTRIM. De vertegenwoordiging van verschillende disciplines binnen onze universiteit biedt de mogelijkheid tot verbreding van mijn wetenschappelijke blik. Mijn roep om bijvoorbeeld meer balans tussen voorlichting en beleid kan zo hopelijk cen luisterend oor vinden. Ik hoop dat deze mogelijkheid ook benut zal gaan worden in de tockomst

De laatste persoon die ik wil bedanken is mijn vrouw 'Trudy Rohn. Trudy, ik dank je voor je relativerende woorden als ik eens doordraafde, voor jouw steun gedurende de afgelopen jaren, jouw optimisme, dynamiek, levenslust en licfde.

Waarde toehoorders, we zijn aan het einde gekomen van deze rede. Nog een laatste preventieve opmerking voor de receptie. Voor de verslaafde rokers, ofwel de nicotinejunks onder $u$, het zal duidelijk zijn dat kankerpreventie vraagt om een goed niet-roken beleid. Roken is dan ook niet toegestaan tijdens de receptie, een lekkere borrel wel.

Ik heb gezegd. 
Erratum pag 5: Er wordt aanbevolen om per DAG niet meer dan drie glazen alcohol te drinken. 


\section{Geraadpleegde literatuur}

Backbier, E., \& De Vries, H. (1993). Attitude, sociale invloed en eigen effectiviteit ten aanzien van stoppen met roken tijdens de zwangerschap. Gedrag en Geqandheid, $21,2,63-73$.

Bleiker, E., \& Van der Linden, M. (1998). Erfelijkheidsonderzoek bij het familiair voorkomen van kanker. Maandblad voor de Geestelijke Geqondheid, 53, 1186-1197.

Bolman, C., \& De V'ries, H. (1998). Intramuraal stoppen met roken. Cordical, 19, 13-16.

Bracht, N. (1990). Health promotion at the community level. Newbury Park: Sage Publications.

Brug, J. (1997). The development and impact of computer-tailored nutrition cducation. (dissertation). Maastricht: Department of Health Education and Promotion, Maastricht University.

Brug, J., Van Asscma, P., Lenderink, T., Glanz, K., Kok, G.J. (1994). Self-rated dietary fat intake: Association with objective assessment of fat, psychosocial factors and intentions to change. Journal of Nutrition and Education, 26, 218-223.

Brug, J., Steenhuis, I., Van Assema, P. \& De Vries, H. (1996). The impact of a computer tailored nutrition intervention. Preventive Medicine, 25, 236-242.

Colditz, G.A., Cannuscio, C.C., \& Lindsay Frazier, A. (1997). Physical activity and reduced risk of colon cancer: implications for prevention. Cancer Causes and Control, 8, 649-667.

Cornelisse, C.J., \& Devilec, P. (1997). Facts in cancer genetics. Patiën Edmciation cr Connseling, 32, 9-17.

De Nooijer, J., Lechner, L., \& De Vries, H. (1998). Verstandig genieten van de zon. Maastricht: Vakgrocp Gezondheidsvoorlichting.

De Vrics, H. (1993). Primaire preventic komt van de grond. Tijdsclinft Kanker, 17, 150-153.

De Vries, H. (1995). Socio-economical differences in smoking: Dutch Adolescents' belicfs and behavior. Social Science eir Medicine, 41, 419-424.

De Vries, H., Backbier, E., Dijkstra, M., van Breukelen, G., Parcel, G.S., \& Kok, G.J. (1994). A Dutch social influence smoking prevention approach for vocational school students. Health Edwcation Researih, 9, 365-374.

De Vries, H., \& Kok, G.J. (1996). Integratie van modellen in de gezondheidspsychologie en voorlichting: een toepassing van het $A B C$ planningsmodel. Gedrag is Geandbeid, 24, 342-352.

De Vries, H., \& Mudde, A. (1998). Predicting stage transitions for smoking cessation applying the Atritude - Social influence - Efficacy Model. Psychology is Heallh, 13, 369-385.

De Vries, H., \& Brug, J. (1999). Computer-tailored interventions motivating people to adopt health promoting behaviours; introduction to a new approach. Patient Edscation and Comnseling, 34, 99-105.

De Koning, H.J., \& Van Ballegooijen, M. (1997). Screening op kanker. In 
Volksgezondheid Toekoms Verkenning 1997; Effecten van preventie (pp. 256-277). XX; Rijksinstituut voor Volksgezondheid en Milieu.

Dijkstra, A. (1998). Computer-tailored interventions for smoking cessation: targeting smokers with low intention to quit (dissertation). Maastricht: Department of Health Education and Promotion, Maastricht University.

Dijkstra, A., De V'rics, H., \& Bakker, M. (1996). Pros and cons of quitting, selfcfficacy and the stages of change in smoking cessation. Joumal of Consulting and Clinical Pyichology, 64, 758-776.

Dijkstra, A., De Vries, H., Roijackers, J., \& Van Breukelen, G. (1998). Tailoring information to enhance quitting in smokers with low motivation to quit: Three basic efficacy questions. Psycholog ir Health, 17, 513-519.

Dijkstra, A., De Vries, H., Roijackers, J. \& Van Breukelen. G. Tailored interventions to communicate stage-matched information to smokers in different motivational stages. Journal of Consulting and Clinical Psychology' (in press).

Dijkstra, M. (1995). Development, implementation, and eyaluation of two Dutch smoking prevention programs (disserfation). Maastricht: Department of Health Education and Promotion, Maastricht University.

Dijkstra, M., Mesters, I., De Vries, H., Van Breukelen, G. \& Parcel, G.S. (1999). Effectiveness of two Dutch smoking prevention program with boosters. Health Education Research (in press).

Doll, R. (1989). The prevention of cancer: Opportunitics and challenges. In I'. Heller, B. Davey, \& L. Bailey (eds.), Reducing the risk of camers (pp.14-24). London: Hodder \& Stoughton.

Doll, R., \& Peto, R. (1981). The causes of cancer: Quantitative estimate of avoidable risks of cancer in the United States today. Joumal of the National Camer Institute, 66, 1191-1308.

Drenthen, A.J.M., van Essen, G.A., Hock, D., \& Van Lidth de Jeude, C.P. (1997). Verbetering grieppreventie en cervixscreening in de huisartspraktijk. Medisch Contact, 52, 1346-1347.

Engels, R.C.M.E., Knibbe, R.A., De Vries, H., Drop, M.J. \& Van Breukelen, G.J.$P$. Influences of parental and best friends' smoking and drinking on adolescent use: A longitudinal study. Journal of Applied Social Psyclolog' (in press).

Flay, B.R. (1985). Psychosocial approaches to smoking prevention: a review of findings. Health Psychology, 4, 449-488.

Gammon, M.D., John, E.M., \& Britton, J.A. (1998). Recreational and occupational physical activities and risk of breast cancer. Journal of the National Canter Institute, 90, 100-117.

Gerards, F. (1991). Health counseling, strategic voor begeleiding van patiënten. Tijdschrift gezondheidsvoorlichting, 8, 15-17.

Glynn, T.J. (1989). Essential elements of school-based smoking prevention programs. Joumal of School Health, 59, 181-188.

Green, L.W., \& Kreuter, M.W. (1991). Health promotion planning; an educational and environmental appracts. Palo Alto: Mayfield Publishing Company. 
Hansen, W.B. (1992). School-based substance abuse prevention: a review of the state of art in curriculum, 1980-1990. Health Education Research, 7, 403-430.

Hunter, D.J., Spiegelman, D., Adami, H.O. et al. (1996). Cohort studies of fat intake and risk of breast cancer - a pooled analysis. New England Journal of Medicine, 334, 356-361.

Hupkes, J., Bik, M., Ekelmans, M., van Ooij, M., De Rover, C., \& De Jong, R. (1998). Een visie op voorlichtingsstrategie en voorlichtingsproducten bij cervixscreening. Tiel: Gemeenschappelijke Gezondheidsdienst Rieverenland.

Klankbordgroep Bevolkingsonderzoeken (1997). (Proces)evaluatie van het onderzoek naar borstkanker in de GGD-regio's van Midden en Zuid-Limburg. Geleen: Klankbordgroep Bevolkingsonderzoeken.

Kok, G.J. (1985). Een model van gedragsverandering via voorlichting. Nederlands Tijisclorift voor de Psychologie, 40, 71-76.

Kok, G.J. (1987). Gezondheidsvoorlichting en -Oproeding, GVO. In: Damoiseaux, V., Gerards, F.M., Kok, G.J., Nijhuis, F.M. Gezondheidswoorlichting en Opuoeding; ran analyse tot effecten. Assen/Maastricht: Van Gorcum, p. 1-12.

Kok, G.J., \& Green. L.W. (1990). Research to support health promotion in practice; a plea for increased cooperation. Health Promotion International, 5, 303-308.

Laforge, R.G., Velicer, W.F., Levesque, D., Fava, J.L., Hill, D.J., Schofield, P., Fan, D., De Vries, H., Shisana, W.O. \& Conner, M. (1998). Measuring support for tobacco control policy in six countries. Tobacio Control, 7, 241-247.

Lechner, L. (1998). Social psyctological deteminamts of bealth nisk bebatiors related to cancer and CVD (dissertation). Maastricht: Department of Health Eduation and Promotion, Maastricht University.

Lechner, L., Brug, J., \& De Vries, H. (1997). Misconception of fruit and vegetable consumption: interpretation and consequences. Joumal of Nutrition Education, 29, 313-320.

Lechner, L., \& De Vries, H. (1997). Nederlanders in de zon; risico-gedrag en determinanten. Tijdschrift yoor Sociale Gezondheidszorg, 75, 61-69.

Lechner, L., De Vries, H., \& Offermans, N. (1997). Participation in a Breast Cancer Screening Program: Influence of past behavior and determinants on future screening intention. Preventive Medicine, 26, 473-482.

Lechner, L., De Nooijer, J., \& De Vries, H. (1998). Vroege ontdekking van kanker: een gedrags- en determinantenanalyse onder de Nederlandse bevolking. Maastricht: Vakgroep Gezondheidsvoorlichting.

Lechner, L., Brug, J., De Vries, H., Van Assema, P., \& Mudde, A. (1998). Stages of change for fruit, vegetable and fat intake: consequences of misconception. Health Education Research, 13, 1-11.

Leer, E.M., Cleton, F.J., \& Van Leeuwen, F.E. (1999). Signaleringsrapport kanker. Amsterdam: Nederlandse Kankerbestrijding.

Lehrman, C. (1997). Translational behavioral research in cancer genetics. Preventive Medicine, 26, S65-69.

LETB (Landelijk Evaluatie Team voor bevolkingsonderzoek naar borstkanker) 
(1990). Landelijke evaluatie van bevolkingsonderzoek naur borstkanker in Nederland 1996. Vol. V. Rotterdam: Erasmus Universiteit, Instituut Maatschappelijke Gezondheidszorg.

Leurs, M. (1999). De nieuwe Nederlandse norm bewegen. Tijdschrift voor Sociale Geqondleidszorg, 77, 192-193.

Mudde, A.N. (1994). The development and evaluation of a community and mass media approach 10 smoking cessation. Maastricht: Maastricht University, The Netherlands.

Nudde, A.N., De Vries, H. \& Dolders, M.G.T. (1995). Evaluation of a Dutch community-based smoking cessation intervention. Preventive Medicine, 24, 61-70.

Mudde, A.N., \& De Vries, H. (1997) 'Stoppen met roken'-advisering in de huisartspraktijk, de vruchtbare ontwikkeling van de minimale interventiestrategic. Medisch Contact, 52: 789-90.

Oldenburg, B., Hardcastle, M., \& Kok, G.J. Diffusion of innovations. In: Glanz, K., Lewis, F.M., \& Rimer, B. (1997). Health bebavior and bealth ediscation; thenty researd and practice (pp. 270-286). San Francisko: Jossey-Bass Publishers.

Patc, P.R., Pratt, M., Blair, S.N. et al. (1995). Physical activity and public health. A recommendation from the centers for disease control and prevention and the american college of sports medicine. Jouranl of the American Medical Association, 273, 402-407.

Pieterse, M.E., Bockema, A.R., Mudde, A.N., Seydel, E.R. \& de Vries, H. (1992). Stoppen met roken via de huisartspraktijk; uitvoerbaarheid en effectiviteit van de minimale interventiestratcgie. Hwisarts en wetenschap, 35, 338-341,

Pieterse, M.E. (1999). Deselopment, evaluation and diffision of the minimal intenvention strategy' against smoking for General Practitioners (dissertation). Enschede: University of Twente, The Netherlands.

Prochaska, J.O., \& DiClemente, C.C. (1985). Stages and processes of self-change of smoking: toward an integrative model of change. Journal of Consutting and Clinical Psibolog', 51, 390-395.

Rogers, E.M. (1995). Diffesion of innovations. New York: The Free Press.

Ruwaard, D., \& Kramers, P.G.N. (1997). Volksgezondheid Toekomst Verkenning 1997: De som der delen. Den Haag: RIVMI/Elsevier-De Tijdstroom.

Smith-Warner, S.A., Spiegelman, D. Yaun, S.S. et al. (1998). Alcohol and breast cancer in women. A pooled analysis of cohort studies. Journal of the American Medical Association, 279, 535-540.

Stivoro (1999). Jaarverslag 1998. Den Haag: Stichting Volksgezondheid en Roken.

Tones, K., \& 'Tilford, S. (1994). Health edwcation: effectiveness, efficieny' and equity. London: Chapman \& Hall.

Townsend, J. (1996). Price and consumption of tobacco. British Medical Bulletin, 52, $132-142$.

Van Assema, P. (1993). The development, implementation and evaluation of a community health project (dissertation). Maastricht: Department of Health Education and Promotion, Maastricht University.

Van Assema, P., Pieterse, M., Kok, G.J, Eriksen, M., \& De Vries, H. (1993). The 
determinants of four cancer-related risk behaviors. Health Education Research, 8, 461 472.

Van Baal, M. (1997). Trendcijfers gezondheidsenquetc; aspecten van (on)gezond gedrag, 1989-1996. Maandbericht gerondheidsstatistiek, 16, 5-21.

Van Ballegooijen, M., Bos, A.B., Van den Akker, M.E., Van Oortmarssen, G.J., Boer, R., Mecrding, W.J., \& Habbema, J.D.F. (1997). Een eerste beschrijuing van de praktijk van ebt bevolkingsonderzoek naar baarmoederbalskanker in Nederland in 1994 op grond van gegevens sit bet centrale Palga. Rotterdam: Erasmus Universiteit Rotterdam, Insituut Maatschappelijke Gezondheidszorg.

Van den Brandt, P.A. (1997). Voeding en de etiologie van kanker. Tijdsclsrift Kanker, 21, 18-30.

Van den Brandt, P.A., Van 't Veer, P., Goldbohm, R.A., Dorant, E., Volovics, A., Hermus, R.J., \& Sturmans, F. (1993). A prospecrive cohort study on dietary fat and the risk of post menopausal breast cancer. Cancer Research, 53, 75-82.

Van den Brandt, P.A., Goldbohm, R.A., Van 't Veer, P., Volovics, A., Hermus, R.J., \& Sturmans, F. (1997). A large scale prospective cohort study on diet and cancer in The Netherlands. Journal of Clinical Epidemolog', 43, 285-295.

Visser, A., \& Bleiker, E. (1997). Genetic education and counseling. Patient Education and Couneling, 32, 1-7.

Willemsen, M.C. (1997). Employees who kick the babit: The effectiveness of smoking cessation programs in worksites (dissertation). Maastricht University, The Netherlands.

Willemsen, M.C., De Vries, H., Van Breukelen, G. \& Genders, R. (1998). Longterm effectiveness of two Dutch worksite cessation programs. Heallb Education ei Belsaviour, 25, 418-435.

Willemsen, M.C., De Zwart, W.M., \& Mooy, J.M. (1998). Effectiviteit van overheidsmaatregelen om het tabaksgebruik terug te dringen. In: Tabaksontmoedigingsbeleid; gerondbeidsrapportage. Utrecht: Netherlands School of Public Health. 